\title{
Description of the pupa of Lopesia brasiliensis Rübsaamen (Diptera, Cecidomyiidae)
}

\author{
Valéria C. Maia \\ Departamento de Entomologia, Museu Nacional. Quinta da Boa Vista, São Cristóvão, 20940-040 Rio de Janeiro, Rio de \\ Janeiro, Brasil. E-mail: maiavcid@acd.ufri.br
}

\begin{abstract}
Lopesia brasiliensis Rübsaamen, 1908 was described as male, female and larva, based on material from the States of Rio de Janeiro and Santa Catarina (Brazil). This cecidomyiid induces leaf galls on Ossaea sp. (Melastomataceae). The pupa is described and illustrated for the first time.

KEY WORDS. Gall; Melastomataceae; morphology; Ossaea; taxonomy.
\end{abstract}

RESUMO. Descrição da pupa de Lopesia brasiliensis Rübsaamen (Diptera, Cecidomyiidae). Lopesia brasiliensis Rübsaamen, 1908 foi descrita como macho, fêmea e larva, com base em material dos Estados do Rio de Janeiro e Santa Catarina (Brasil). Esse cecidomiídeo induz galhas foliares em Ossaea sp. (Melastomataceae). A pupa é descrita e ilustrada pela primeira vez.

PALAVRAS-CHAVE. Galha; Melastomataceae; morfologia; Ossaea; taxonomia.

Lopesia was described by RÜBSAAMEN (1908) to a single species - L. brasiliensis, based on larva and adults of both sexes. The type material was collected in the State of Rio de Janeiro and Santa Catarina (Brazil). In this paper, the pupa of $L$. brasiliensis is described and illustrated for the first time based on material from the Reserva Biológica da União (Casimiro de Abreu, Rio de Janeiro).

\section{MATERIAL AND METHODS}

The studied material comprises five pupal exuviae and a single pupa and was donated by Ricardo Ferreira Monteiro (Universidade Federal do Rio de Janeiro, Departamento de Ecologia). The pupa and pupal exuviae were prepared and mounted on slides, following the methods described in GAGNÉ (1994).

\section{Lopesia brasiliensis}

Figs 1-7

Pupa. Length: 3.9-4.6 mm ( $\mathrm{n}=3)$. Head (Fig. 1): antennal horn bifid, well developed and with $0.06-0.08 \mathrm{~mm}$ of length; two pairs of vertical papillae, one nonsetose and one with a short seta (length: 0.02-0.03 mm) (Fig. 2); two pairs of lower facial papillae (one setose and one nonsetose; Fig. 3); three pairs of lateral facial papillae (one setose and two nonsetose, Fig. 4); upper cephalic margin laterally thickened. Thorax: prothoracic spiracle sclerotized, setiform and long (length: 0.45-0.53 mm, Fig. 5). Abdome: segments 1-8 with dorsal spines (Figs 6 and 7), varying in number (Tab. I); segments $2-6$ with proeminent spiracles; terminal segment with two conspicuous apical lobes (Fig. 7).

Material: BRAzIL, Rio de Janeiro: Casimiro de Abreu (Reserva Biológica da União), 5 pupal exuviae and 1 pupa, R.F. Monteiro leg., 27.X.2006. On Ossaea sp. (Melastomataceae).

Table I. Distribution of dorsal spines on pupal abdominal segments 1-9 in four specimens of Lopesia brasiliensis. (W) Well developed spines, (S) short spines.

\begin{tabular}{|c|c|c|c|c|c|c|c|c|}
\hline \multirow{3}{*}{$\begin{array}{c}\text { Abdominal } \\
\text { segment }\end{array}$} & \multicolumn{8}{|c|}{ Number of spines in specimens } \\
\hline & \multicolumn{2}{|c|}{1} & \multicolumn{2}{|c|}{2} & \multicolumn{2}{|c|}{3} & \multicolumn{2}{|c|}{4} \\
\hline & W & $S$ & W & $S$ & W & $S$ & W & $S$ \\
\hline 1 & 0 & 4 & 0 & 4 & 0 & 4 & 0 & 4 \\
\hline 2 & 8 & 0 & 8 & 0 & 9 & 0 & 9 & 0 \\
\hline 3 & 7 & 0 & 7 & 0 & 9 & 0 & 7 & 1 \\
\hline 4 & 6 & 1 & 6 & 1 & 6 & 0 & 8 & 0 \\
\hline 5 & 6 & 1 & 6 & 1 & 7 & 0 & 8 & 0 \\
\hline 6 & 5 & 0 & 5 & 0 & 5 & 0 & 7 & 0 \\
\hline 7 & 8 & 0 & 8 & 0 & 5 & 0 & 5 & 0 \\
\hline 8 & 3 & 0 & 3 & 0 & 5 & 0 & 4 & 2 \\
\hline 9 & 0 & 0 & 0 & 0 & 0 & 0 & 0 & 0 \\
\hline
\end{tabular}

\section{ACNOWLEDGMENTS}

To Ricardo F. Monteiro (Universidade Federal do Rio de Janeiro) for donating the material. 


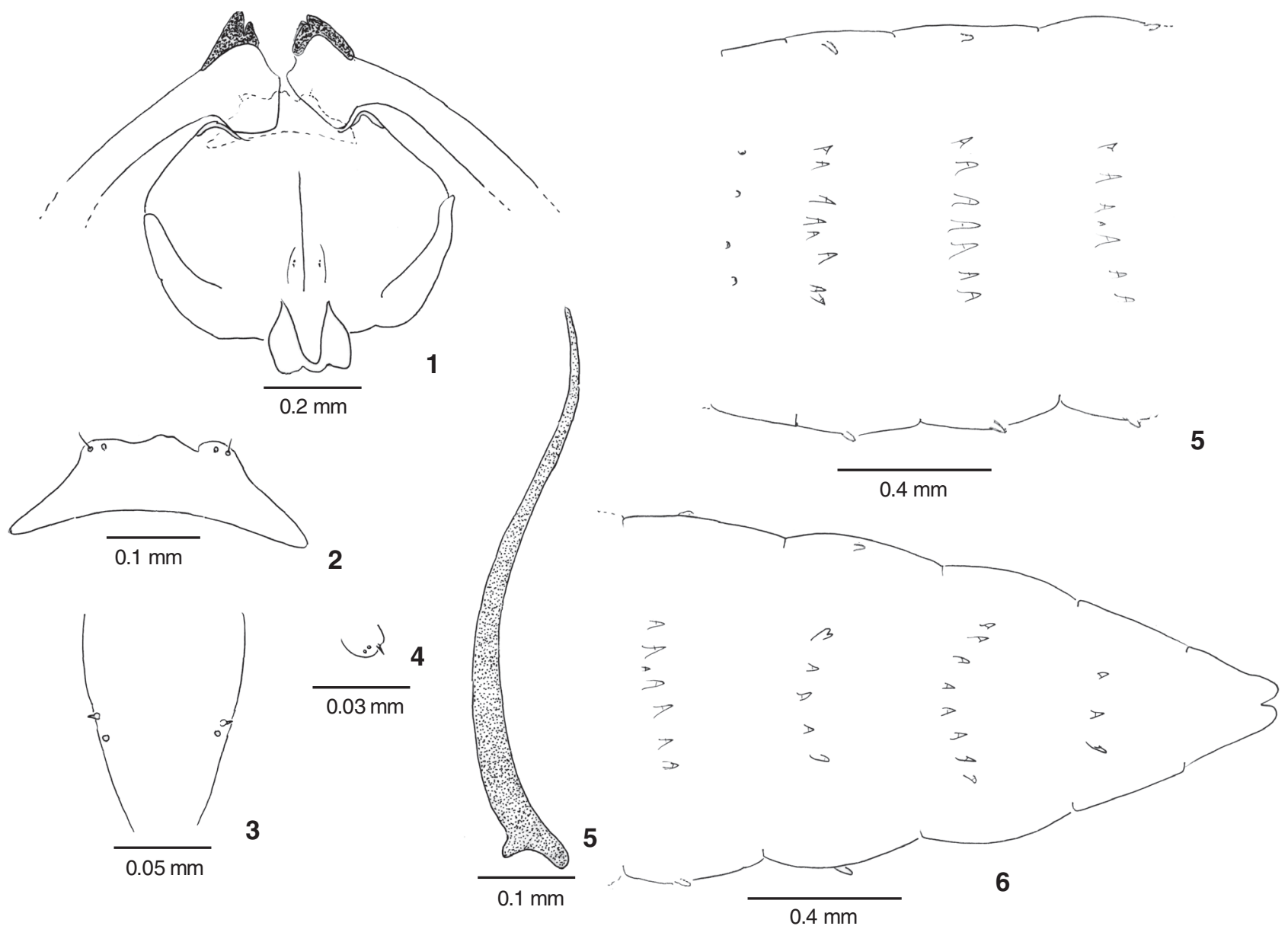

Figures 1-7. Pupa of Lopesia brasiliensis: (1) head, frontal view; (2) vertical papillae, dorsal view; (3) lower facial papillae, ventral view; (4) lateral facial papillae, ventral view; (5) prothoracic spiracle; (6) abdominal segments 1-4, ventral view; (7) abdominal segments 5-9, ventral view.

\section{REFERENCES}

GAGNÉ, R.J. 1994. The gall midges of the Neotropical region. Ithaca, Comstock Cornell University Press, 352p.
RÜBSAAMEN, E.H. 1908. Beiträge zur Kenntnis aussereuropäischer Zoocecidien. III. Beitrag [cont.]: Gallen aus Brasilien und Peru. Marcellia 7: 15-79.

Received in 07.VIII.2007; accepted in 13.XI.2007. 